\title{
Analisis Ketahanan dan 8 Fungsi Keluarga di Provinsi Jambi Serta Faktor-Faktor yang Mempengaruhinya
}

\author{
Fachroerrozi Hoesni $^{1}$, Firmansyah ${ }^{2}$ \\ ${ }^{1}$ Universitas Batanghari Jambi \\ ${ }^{2}$ Universitas Jambi \\ Correspondence email: rozi.hoesni@gmail.com
}

\begin{abstract}
Abstrak. Untuk pelaksanaan 8 fungsi keluarga di Provinsi Jambi, Mayoritas keluarga di Provinsi Jambi (86,60 \%) tidak mengetahui tentang 8 fungsi keluarga. Pelaksanaan 8 fungsi keluarga di Provinsi Jambi yang terbanyak $(43,82 \%)$ kategori cukup, fungsi agama, fungsi sosial budaya, fungsi cinta kasih, fungsi perlindungan, fungsi reproduksi, fungsi sosialisasi dan pendidikan, ekonomi, dan fungsi lingkungan pada keluarga di perkotaan dan perdesaan Provinsi Jambi adalah berbeda kecuali fungsi lingkungan. Untuk keaktifan ketahanan keluarga di Provinsi Jambi dapat disimpulkan, mayoritas keluarga di Provinsi Jambi tidak mengetahui mengenai Kelompok Kegiatan (Poktan) Tribina (BKB, BKR, BKL), PIK R/M, UPPKS dan PPKS. Semakin tinggi pendidikan kepala keluarga maka semakin tinggi pelaksanaan 8 fungsi keluarga di Provinsi Jambi.
\end{abstract}

Kata Kunci : 8 fungsi keluarga; analisis ketahanan

Abstract. For the implementation of 8 family functions in Jambi Province, the majority of families in Jambi Province (86.60\%) do not know about 8 family functions. The implementation of 8 family functions in Jambi Province was the most (43.82\%) enough categories, religious functions, socio-cultural functions, love functions, protection functions, reproductive functions, socialization and education functions, economics, and environmental functions in urban families and Jambi Province villages are different except for environmental functions. For the activeness of family resilience in Jambi Province, it can be concluded that the majority of families in Jambi Province are unaware of the Tribina Activity Group (BKB, BKR, BKL), PIK R / M, UPPKS and PPKS. The higher the education of family heads, the higher the implementation of 8 family functions in Jambi Province.

Keyword: 8 family functions; resilience analysis

\section{PENDAHULUAN}

Salah satu prasyarat untuk meningkatkan kualitas hidup manusia dan masyarakat Indonesia adalah dengan mewujudkan penduduk Indonesia yang tumbuh secara seimbang dengan pengendalian kuantitas penduduk melalui Keluarga Berencana (KB) dan kualitas penduduk melalui pembangunan keluarga. Sesuai amanat Undang-Undang Nomor 52 Tahun 2009 tentang Perkembangan Kependudukan dan Pembangunan Keluarga, penduduk harus menjadi titik sentral dalam pembangunan berkelanjutan di Indonesia. Pembangunan berkelanjutan adalah pembangunan terencana. Dengan penduduk Indonesia yang tumbuh secara seimbang, maka daya tampung dan daya dukung lingkungan tetap terjaga sehingga akan memudahkan membangun manusia Indonesia sebagai sumberdaya pembangunan yang produktif dan berdaya saing, serta sebagai insan dan anggota masyarakat yang dapat hidup secara rukun, damai, gotong royong, patuh pada hukum, dan aktif dalam bermasyarakat.

Salah satu isu strategis dan permasalahan, serta tantangan pengendalian kuantitas penduduk Indonesia adalah pembangunan keluarga yang dilakukan melalui pembinaan ketahanan dan kesejahteraan keluarga yang ditandai dengan peningkatan pemahaman dan kesadaran fungsi keluarga. Peningkatan pemahaman dan kesadaran orang tua dan anggota keluarga mengenai peran dan fungsi keluarga dalam pembinaan ketahanan dan kesejahteraan keluarga, yang meliputi antara lain fungsi cinta kasih, perlindungan, hubungan sosial, reproduksi, agama, pendidikan, ekonomi, dan lingkungan sosial, dalam membentuk keluarga kecil bahagia dan sejahtera.

Arah kebijakan dan strategi pembangunan bidang kependudukan dan keluarga berencana yang tercantum dalam RPJMN 2015-2019 dan Renstra Badan Kependudukan dan Keluarga Berencana Nasional (BKKBN) Tahun 2015-2019 adalah meningkatkan peran dan fungsi keluarga dalam pembangunan keluarga melalui : penguatan fungsi keluarga yang juga merupakan upaya pelaksanaan revolusi mental mencakup (i) fungsi cinta kasih yaitu bahwa keluarga merupakan wahana menumbuhkan rasa cinta dan kasih sayang,; (ii) fungsi perlindungan untuk menciptakan suasana aman, nyaman, damai, dan adil bagi seluruh anggota keluarganya; (iii) fungsi sosial budaya yaitu untuk pembinaan dan persemaian nilai-nilai luhur budaya sosial; (iv) fungsi agama yaitu untuk pembinaan kehidupan beragama; (v) fungsi pendidikan yaitu sebagai tempat terbaik untuk proses sosialisasi dan pendidikan bagi anak, (vi) fungsi ekonomi untuk membina kualitas kehidupan ekonomi dan kesejahteraan keluarga; (vii) fungsi lingkungan untuk membina anggota keluarga agar mampu hidup harmonis dengan lingkungan masyarakat dan alam sekitar; dan (viii) 
fungsi reproduksi yang mempunyai makna keluarga sebagai tempat diterapkannya cara hidup sehat khususnya dalam kehidupan reproduksi, termasuk memberikan pemahaman bagi remaja dalam memasuki kehidupan berkeluarga.

Adapun tujuan kajian tentang Analisis Ketahanan dan Fungsi Keluarga di Provinsi Jambi serta FaktorFaktor yang mempengaruhinya, diantaranya: (a) untuk mengetahui perbedaan tingkat pelaksanaan 8 fungsi keluarga berupa fungsi cinta kasih, perlindungan, sosial budaya, agama, pendidikan, ekonomi, lingkungan, reproduksi berdasarkan lokasi (perkotaan dan perdesaan) pada keluarga di Provinsi Jambi; (b) untuk mengetahui perbedaan tingkat pengetahuan dan keaktifan keluarga tentang ketahanan keluarga berupa Bina Keluarga Balita (BKB), Bina Keluarga Remaja (BKR), Bina Keluarga Lansia (BKL), Pusat Informasi dan Konseling Remaja (PIK-R), dan Pusat Pelayanan Keluarga Sejahtera (PPKS) berdasarkan lokasi (perkotaan dan perdesaan) pada keluarga di Provinsi Jambi; dan (c) untuk menganalisis pengaruh faktor pendidikan terhadap keaktifan ketahanan keluarga dan pelaksanaan 8 fungsi keluarga pada keluarga di Provinsi Jambi

\section{METODE}

Penelitian tentang Kajian Analisis Ketahanan dan Fungsi Keluarga di Provinsi Jambi serta Faktor-Faktor yang Mempengaruhinya menggunakan metode penelitian kuantitatif. Penelitian kuantitatif adalah penelitian ilmiah yang sistematis terhadap bagian-bagian dan fenomena serta hubungan-hubungannya. Tujuan penelitian kuantitatif adalah mengembangkan dan menggunakan model-model matematis, teori-teori dan/atau hipotesis yang berkaitan dengan fenomena alam. Creswell (2014) yang menyatakan penelitian kuantitatif merupakan pendekatan untuk menguji teori objektif dengan menguji hubungan antar variabel. Variabel ini, pada gilirannya, dapat diukur dengan menggunakan instrumen, sehingga data jumlah dapat dianalisis dengan menggunakan prosedur statistik. Dalam penelitian kuantitatif, survei lebih merupakan pertanyaan tertutup, sementara dalam penelitian kualitatif berupa wawancara mendalam dengan pertanyaan terbuka (Hendri, 2009). Data yang digunakan dalam penelitian ini adalah data sekunder. Moehar (2002) menyatakan data sekunder adalah merupakan data yang telah tersedia dlam berbagai bentuk atau data yang sudah diolah. Sedangkan menurut Erlina (2008), data sekunder adalah data yang telah dikumpulkan oleh lembaga pengumpulan data dan dipublikasikan kepada masyarakat pengguna data. Sumber data sekunder yang dipergunakan dalam penelitian ini diperoleh dari Survei Kinerja dan Akuntabilitas Program (SKAP) BKKBN Tahun 2018.

\section{Uji Beda Rata-Rata}

Untuk mengetahui perbedaan perbedaan tingkat pengetahuan dan keaktifan keluarga tentang ketahanan keluarga dan perbedaan tingkat pelaksanaan 8 fungsi keluarga digunakan uji beda rata-rata dengan rumus sebagai berikut :

$$
t-\text { hitung }=\frac{\overline{X_{1}}-\overline{X_{2}}}{\sqrt{\frac{S_{1}^{2}}{n_{1}}+\frac{S_{2}^{2}}{n_{2}}}}
$$

Keterangan $: \overline{X_{1}}=$ Rata-rata tingkat pengetahuan dan keaktifan keluarga di Perkotaan; $\overline{X_{2}}=$ Rata-rata tingkat pengetahuan dan keaktifan keluarga di Perdesaan; $S_{1}^{2}=$ Varians tingkat pengetahuan dan keaktifan keluarga di Perkotaan; $S_{2}^{2}=$ Varians tingkat pengetahuan dan keaktifan keluarga di Perdesaan; $n_{1}=$ Jumlah sampel keluarga di Perkotaan; $n_{2}=$ Jumlah sampel keluarga di Perdesaan.

Pasangan hipotesis dan alternatifnya dirumuskan sebagai berikut :

$$
\begin{aligned}
& H_{0}: \overline{X_{1}}=\overline{X_{2}} \\
& H_{1}: \overline{X_{1}} \neq \overline{X_{2}}
\end{aligned}
$$

Keputusannya yaitu :

- Jika $\mathrm{t}_{\text {hitung }}<\mathrm{t}_{\text {tabel}}$, maka $\mathrm{H}_{1}$ ditolak dan $\mathrm{H}_{0}$ diterima

- Jika $\mathrm{t}_{\text {hitung }} \geq \mathrm{t}_{\text {tabel }}$, maka $\mathrm{H}_{1}$ diterima dan $\mathrm{H}_{0}$ ditolak

\section{HASIL DAN PEMBAHASAN}

Delapan Fungsi Keluarga

Survei Kinerja dan Akuntabilitas Program Kependudukan, Keluarga Berencana dan Pembangunan Keluarga (SKAP) tahun 2018 menyebutkan bahwa mayoritas keluarga di Provinsi Jambi $(86,60 \%)$ tidak mengetahui tentang 8 fungsi keluarga, hanya sebagian kecil saja $(13,40 \%)$ yang mengetahui tentang 8 fungsi keluarga. Temuan ini cukup menarik karena sebenarnya keluarga telah penerapan 8 fungsi keluarga dalam keluarga. Istilah 8 fungsi keluarga tidak dikenal luas oleh masyarakat di Provinsi Jambi, sehingga walaupun tanpa disadari mereka telah melaksanakan fungsi tersebut namun responden menyatakan tidak pernah mendengar atau mengetahui istilah 8 fungsi keluarga. BKKBN membagi fungsi keluarga menjadi 8 (delapan) fungsi yang terdiri dari fungsi agama, sosial budaya, cinta kasih, perlindungan, reproduksi, sosialisasi dan pendidikan, ekonomi, dan lingkungan. Setiap fungsi dalam delapan fungsi keluarga mempunyai makna dan peran penting dalam keluarga, yang diharapkan dapat menjadi pijakan dan tuntunan keluarga dalam menjalani kehidupan berkeluarga.

Survei Kinerja dan Akuntabilitas Program Kependudukan, Keluarga Berencana dan Pembangunan Keluarga (SKAP) tahun 2018 menyebutkan bahwa 
pengetahuan masyarakat di Provinsi Jambi mengenai 8 fungsi keluarga yang bersumber dari media yang terbanyak berasal dari Televisi $(62,20 \%)$ dan diikuti spanduk $(31,50 \% 0$ dan poster $(23,10 \%)$. Untuk sumber informasi media yang lain secara rinci tersaji pada tabel berikut.

Tabel 1. Survei Kinerja dan Akuntabilitas Program Kependudukan, Keluarga Berencana dan Pembangunan Keluarga (SKAP) tahun 2018 sumber informasi media

\begin{tabular}{clccc}
\hline \multirow{2}{*}{ No } & \multirow{2}{*}{ Sumber Informasi dari Media } & \multicolumn{2}{c}{ Ya } & Tidak \\
\cline { 1 - 1 } $\mathbf{1}$ & & Radio & 1.90 & 98.10 \\
$\mathbf{2}$ & Televisi & 62.20 & 37.80 \\
$\mathbf{3}$ & Koran & 11.10 & 88.90 \\
$\mathbf{4}$ & Majalah/Tabloid & 5.60 & 94.40 \\
$\mathbf{5}$ & Pamflet/Leaflet/Brosur & 15.30 & 84.70 \\
$\mathbf{6}$ & Flipchart/Lembar Balik & 9.40 & 90.60 \\
$\mathbf{7}$ & Poster & 23.10 & 76.90 \\
$\mathbf{8}$ & Spanduk & 31.50 & 68.50 \\
$\mathbf{9}$ & Banner & 11.40 & 88.60 \\
$\mathbf{1 0}$ & Billboard /Baliho & 18.70 & 81.30 \\
$\mathbf{1 1}$ & Pameran & 2.80 & 97.20 \\
$\mathbf{1 2}$ & Website/Internet & 16.70 & 83.30 \\
$\mathbf{1 3}$ & Mupen Kb & 5.30 & 94.70 \\
$\mathbf{1 4}$ & Mural/Lukisan Dinding/Grafity & 2.40 & 97.60 \\
$\mathbf{1 5}$ & Tidak Satupun di Atas & 27.80 & 72.20 \\
\hline
\end{tabular}

Sumber data: diolah

Sumber informasi mengenai 8 fungsi keluarga selain dari media, juga bisa berasal dari petugas atau masyarakat. Survei Kinerja dan Akuntabilitas Program Kependudukan, Keluarga Berencana dan Pembangunan Keluarga (SKAP) tahun 2018 menyebutkan bahwa pengetahuan masyarakat di Provinsi Jambi mengenai 8 fungsi keluarga yang bersumber dari petugas atau masyarakat yang terbanyak berasal dari Teman/Tetangga/Saudara $(68,70 \%)$, diikuti oleh PPKBD/Sub PPKBD/Kader (46,10 \%), Bidan/Perawat $(44,20 \%)$ dan Perangkat Desa $(43,10 \%)$. Untuk sumber informasi petugas atau masyarakat yang lain secara rinci tersaji pada Tabel berikut.

Tabel 2. Survei Kinerja dan Akuntabilitas Program Kependudukan, Keluarga Berencana dan Pembangunan Keluarga (SKAP) tahun 2018 sumber informasi petugas atau masyarakat

\begin{tabular}{|c|c|c|c|}
\hline \multirow{2}{*}{ No } & \multirow{2}{*}{$\begin{array}{l}\text { Sumber Informasi dari } \\
\text { Petugas/Masyarakat }\end{array}$} & \multicolumn{2}{|c|}{$\%$} \\
\hline & & Ya & Tidak \\
\hline 1 & PLKB/Penyuluh KB & 27.90 & 72.10 \\
\hline 2 & Guru & 14.10 & 85.90 \\
\hline 3 & Tokoh Agama & 14.00 & 86.00 \\
\hline 4 & Tokoh Masyarakat & 27.70 & 72.30 \\
\hline 5 & Dokter & 23.30 & 76.70 \\
\hline 6 & Bidan/Perawat & 44.20 & 55.80 \\
\hline 7 & Perangkat Desa & 43.10 & 56.90 \\
\hline 8 & PPKBD/Sub PPKBD/Kader & 46.10 & 53.90 \\
\hline
\end{tabular}

\begin{tabular}{clcc}
9 & Teman/Tetangga/Saudara & 68.70 & 31.30 \\
$\mathbf{1 0}$ & Tidak Satupun di Atas & 8.50 & 91.50 \\
\hline
\end{tabular}

Sumber data: diolah

Survei Kinerja dan Akuntabilitas Program Kependudukan, Keluarga Berencana dan Pembangunan Keluarga (SKAP) tahun 2018 juga melaporkan bahwa pengetahuan masyarakat di Provinsi Jambi mengenai 8 fungsi keluarga yang bersumber dari institusi yang terbanyak berasal Organisasi kemasyarakatan (Karang taruna, PKK, Aisyah, Fatayat NU, Posyandu, dsb) sebesar 58,70 \%, sedangkan dari institusi lain tersaji pada tabel berikut ini.

Tabel 3. Survei Kinerja dan Akuntabilitas Program Kependudukan, Keluarga Berencana dan Pembangunan Keluarga (SKAP) tahun 2018 sumber dari institusi yang terbanyak berasal Organisasi kemasyarakatan

\begin{tabular}{|c|c|c|c|}
\hline \multirow{2}{*}{ No } & \multirow{2}{*}{ Sumber Informasi dari Institusi } & \multicolumn{2}{|c|}{$\%$} \\
\hline & & Ya & Tidak \\
\hline 1 & Pendidikan formal (sekolah) & 19.10 & 80.90 \\
\hline 2 & $\begin{array}{l}\text { Pendidikan non formal (kursus, les, } \\
\text { pesantren tradisional, dll) }\end{array}$ & 2.90 & 97.10 \\
\hline 3 & $\begin{array}{l}\text { Organisasi kemasyarakatan (Karang } \\
\text { taruna, PKK, Aisyah, Fatayat NU, } \\
\text { Posyandu, dsb) }\end{array}$ & 58.70 & 41.30 \\
\hline 4 & $\begin{array}{l}\text { Kelompok masyarakat (pengajian, } \\
\text { sekolah minggu, remaja masjid, } \\
\text { persekutuan remaja gereja, dsb) }\end{array}$ & 33.70 & 66.30 \\
\hline 5 & $\begin{array}{l}\text { Kelompok Kegiatan (BKB, BKR, } \\
\text { BKL, UPPKS, PIK R) }\end{array}$ & 23.10 & 76.90 \\
\hline 6 & Tidak pernah satupun & 24.30 & 75.70 \\
\hline
\end{tabular}

Sumber data: diolah

\section{Pelaksanaan 8 Fungsi Keluarga}

Dengan dilaksanakannya 8 fungsi keluarga, diharapkan keluarga dapat menjadi keluarga sejahtera secara ekonomi yang berkualitas. Adapun implementasi 8 fungsi keluarga tersebut juga bertujuan untuk menghindari pernikahan usia dini, pencegahan HIV/AIDS, menghindari kenakalan remaja, penyalahgunaan narkoba dan lainnya. Selain itu, implementasi 8 fungsi keluarga tersebut sebagai upaya melestarikan lingkungan merupakan langkah positif, yakni untuk hidup dinamis secara serasi, selaras, dan seimbang dengan alam. Karena itu, dibutuhkan pengelolaan yang baik untuk bersama-sama menjaga lingkungan. 


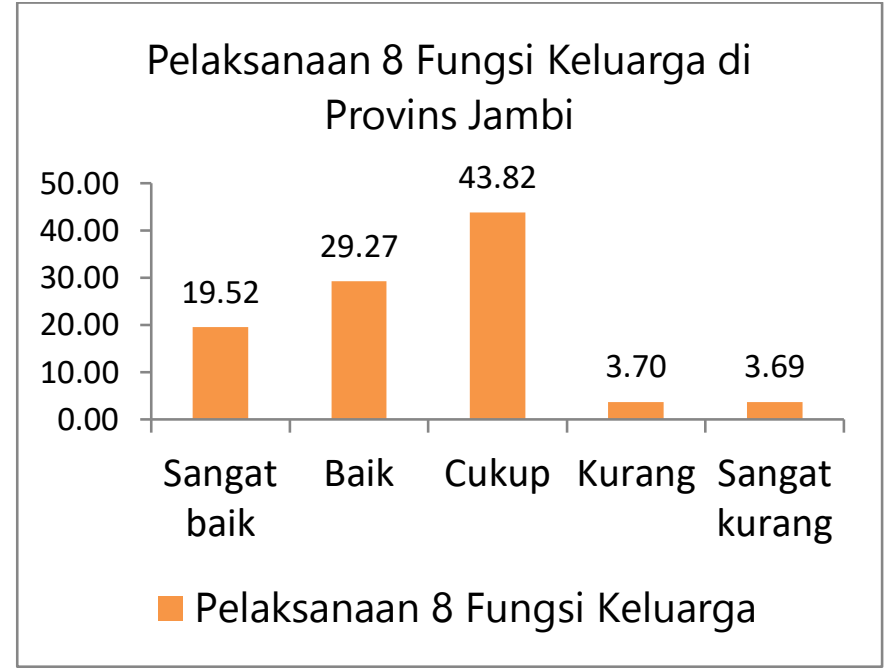

Gambar 1. Pelaksanaan 8 Fungsi Keluarga

Hasil Survei Kinerja dan Akuntabilitas Program Kependudukan, Keluarga Berencana dan Pembangunan Keluarga (SKAP) tahun 2018 salah satunya bertujuan untuk melihat pengetahuan yang dimiliki oleh keluarga di Provinsi Jambi terhadap 8 fungsi keluarga. Selain itu, juga bertujuan untuk mengetahui penerapan 8 fungsi keluarga dalam kehidupan sehari-hari keluarga. Hasil survei ini menyebutkan pelaksanaan 8 fungsi keluarga di Provinsi Jambi yang terbanyak $(43,82 \%)$ kategori cukup, diikuti kategori baik $(29,27 \%)$ dan kategori sangat baik (19,52\%). Ditemukan juga dari survey tersenut yaitu pelaksanaan 8 fungsi keluarga di Provinsi Jambi kategori kurang $(3,70 \%)$ dan sangat kurang $(3,69$ $\%)$.

\section{Pelaksanaan Fungsi Agama}

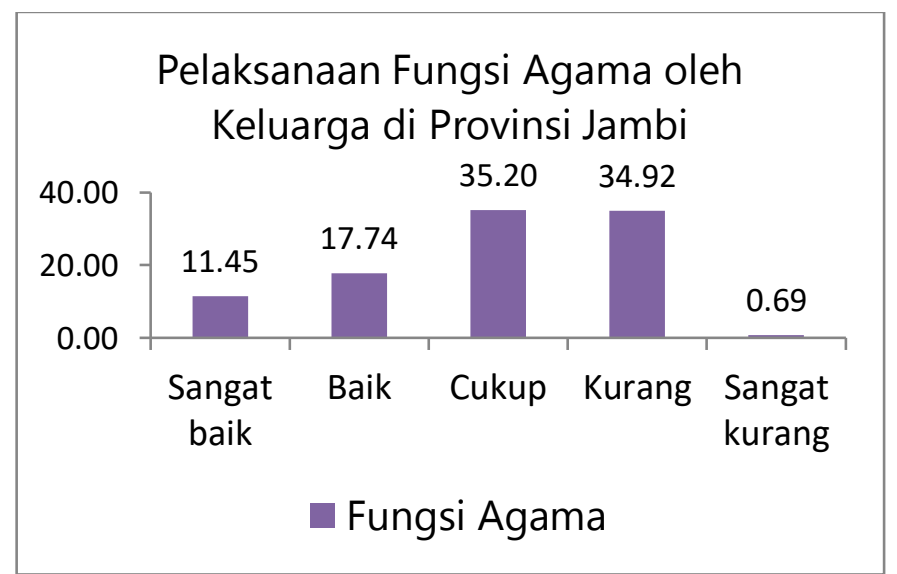

Gambar 2. Pelaksanaan Fungsi Agama oleh Keluarga di Provinsi Jambi

Temuan dari Survei Kinerja dan Akuntabilitas Program KKBPK (SKAP) tahun 2018 ternyata pelaksanaan fungsi agama pada keluarga di Provinsi Jambi yang terbanyak $(35,20 \%)$ kategori cukup, namun banyak juga kategori kurang (34,92 \%). Kemudian survey juga menjelaskan bahwa terdapat 17,74\% pelaksanaan fungsi agama pada keluarga di Provinsi
Jambi kategori baik, bahkan 11,45 \% kategori sangat baik.

\section{Pelaksanaan Fungsi Sosial Budaya}

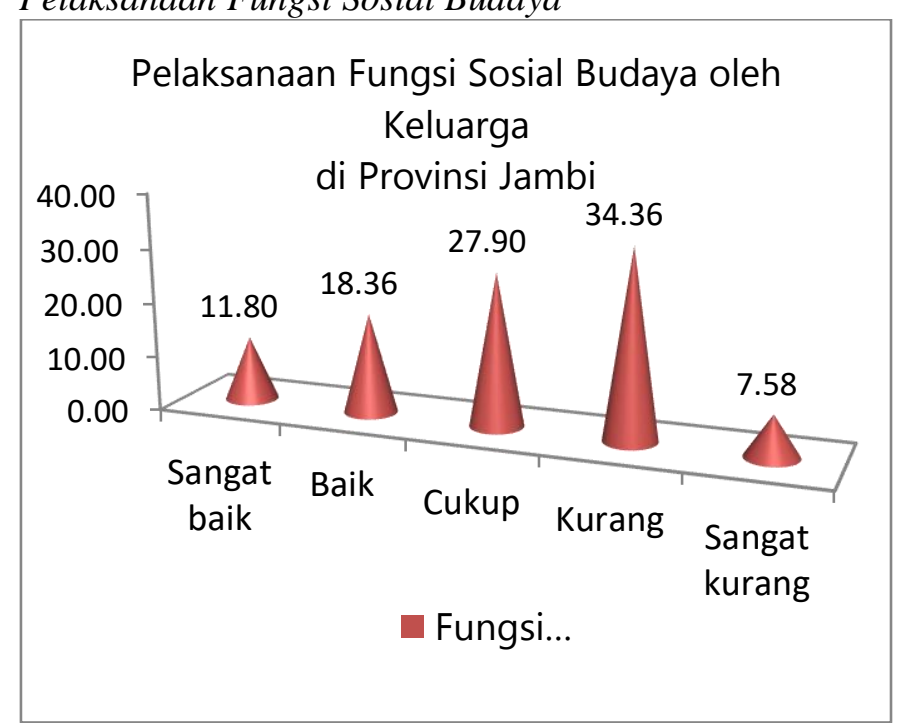

Gambar 3. Pelaksanaan Fungsi Sosial Budaya oleh Keluarga di Provinsi Jambi

Temuan dari Survei Kinerja dan Akuntabilitas Program KKBPK (SKAP) tahun 2018 ternyata pelaksanaan fungsi sosial budaya pada keluarga di Provinsi Jambi yang terbanyak $(34,36 \%)$ kategori kurang, bahkan terdapat $7,58 \%$ pelaksanaan fungsi sosial budaya pada keluarga di Provinsi Jambi masuk kategori sangat kurang. Namun demikian banyak juga pelaksanaan fungsi sosial budaya pada keluarga di Provinsi Jambi yang masuk kategori cukup (34,92 \%). Sekitar 18,36 \% pelaksanaan fungsi sosial budaya pada keluarga di Provinsi Jambi kategori baik dan 11,80\% sangat baik.

\section{Pelaksanaan Fungsi Cinta Kasih}

Temuan dari Survei Kinerja dan Akuntabilitas Program KKBPK (SKAP) tahun 2018 ternyata pelaksanaan fungsi cinta kasih pada keluarga di Provinsi Jambi lebih merata yaitu kategori sedang $(25,46 \%)$, kemudian diikuti sangat baik $(25,37 \%)$ dan baik $(24,52$ $\%)$. Temuan lain adalah terdapat $21,59 \%$ pelaksanaan fungsi cinta kasih pada keluarga di Provinsi Jambi masuk kategori kurang dan sangat kurang $(3,07 \%)$. 


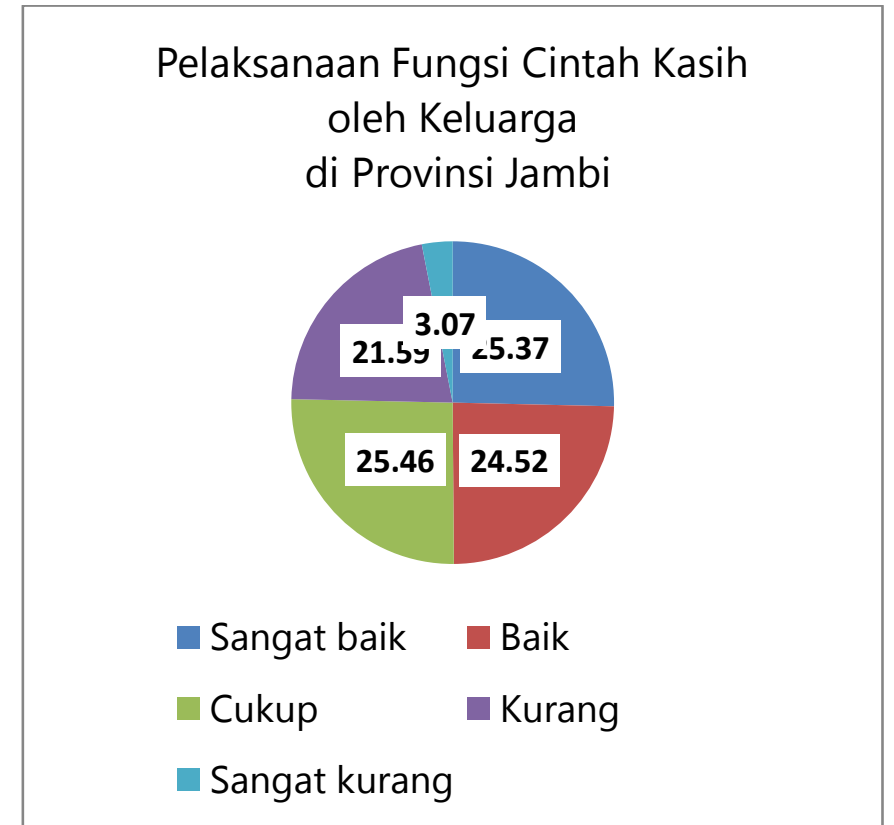

Gambar 4. Pelaksanaan Fungsi Cinta Kasih oleh Keluarga di Provinsi Jambi

\section{Pelaksanaan Fungsi Perlindungan}

Pelaksanaan fungsi perlindungan pada keluarga di Provinsi Jambi yang terbanyak termasuk masuk kategori cukup $(29,35 \%)$. Ini adalah salah satu temuan dari Survei Kinerja dan Akuntabilitas Program KKBPK (SKAP) tahun 2018. Temuan lain dari survey ini adalah pelaksanaan fungsi perlindungan pada keluarga di Provinsi Jambi yang juga agak banyak adalah kategori kurang $(27,06 \%)$, kategori sangat baik dan baik masingmasing 20,29 \% dan 19,18\%. Juga ditemukan dalam survey ini sebagian kecil $(4,12 \%)$ bahwa pelaksanaan fungsi perlindungan pada keluarga di Provinsi Jambi termasuk masuk kategori sangat kurang.

\section{Pelaksanaan Fungsi Perlindungan oleh Keluarga di Provinsi Jambi}

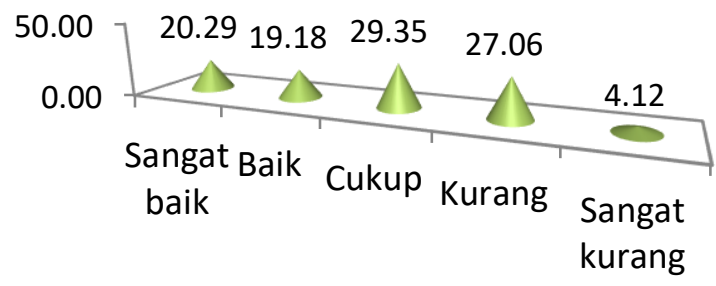

Fungsi...

Gambar 5. Pelaksanaan Fungsi Perlindungan oleh Keluarga di Provinsi Jambi

\section{Pelaksanaan Fungsi Reproduksi}

Temuan dari Survei Kinerja dan Akuntabilitas

Program Kependudukan, Keluarga Berencana dan Pembangunan Keluarga (SKAP) tahun 2018 ternyata pelaksanaan fungsi reproduksi pada keluarga di Provinsi Jambi yang terbanyak kategori kurang (32,31 \%), bahkan ditemukan sebesar 8,27 \% masuk kategori sangat kurang. Disis lain, survey ini juga menemukan sebanyak $30,69 \%$ pelaksanaan fungsi reproduksi pada keluarga di Provinsi Jambi masuk kategori cukup. Temuan lainnya adalah kategori baik dan sangat baik masing-masing $20,21 \%$ dan $8,52 \%$ untuk pelaksanaan fungsi reproduksi pada keluarga di Provinsi Jambi.

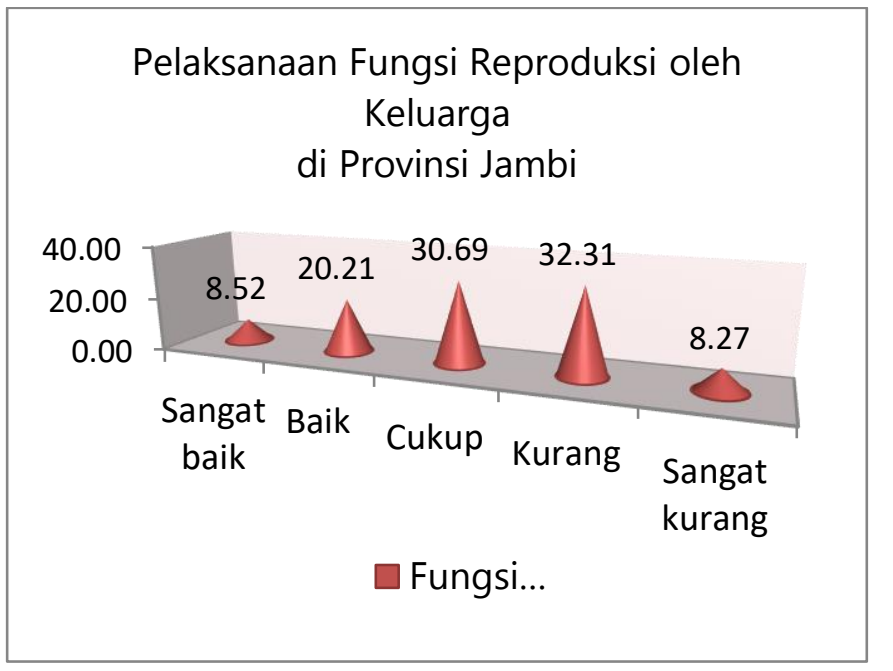

Gambar 6. Pelaksanaan Fungsi Reproduksi oleh Keluarga di Provinsi Jambi

\section{Pelaksanaan Fungsi Sosialisasi dan Pendidikan}

Temuan dari Survei Kinerja dan Akuntabilitas Program KKBPK (SKAP) tahun 2018 ternyata pelaksanaan fungsi sosialisasi dan pendidikan pada keluarga di Provinsi Jambi yang terbanyak kategori cukup $(35,52 \%)$, tetapi sekitar 33,84\% masuk kategori kurang. Disis lain, survey ini juga menemukan sebanyak $2,28 \%$ pelaksanaan fungsi sosialisasi dan pendidikan pada keluarga di Provinsi Jambi masuk kategori sangat kurang. Temuan lainnya adalah kategori baik dan sangat baik masing-masing 16,36 \% dan $12,00 \%$ untuk pelaksanaan sosialisasi dan pendidikan pada keluarga di Provinsi Jambi.

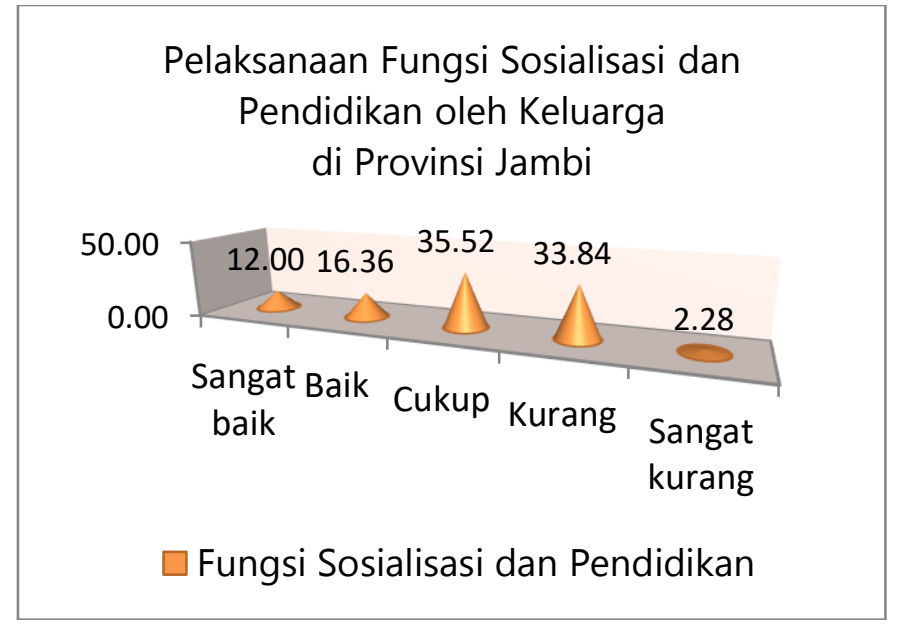

Gambar 7. Pelaksanaan Fungsi Sosialisasi dan Pendidikan oleh Keluarga di Provinsi Jambi 


\section{Pelaksanaan Fungsi Ekonomi}

Menurut Friedman (1998), fungsi ekonomi yaitu mengajarkan kepada anak untuk hidup hemat dan bijaksana dalam mengelola keuangan. Keluarga dalam fungsi ekonomi merupakan tempat membina dan menanamkan nilai-nilai keuangan keluarga dan perencanaan keuangan keluarga, sehingga terwujud keluarga sejahtera. Pada fungsi ini orang tua hendaknya mengajarkan cara mengelola/mengatur keuangan seharihari sejak dini serta menumbuhkan jiwa wirausaha sejak masa kanak-kanak. Diharapkan setiap keluarga mempunyai kemampuan dalam mengelola keuangan.

Pelaksanaan fungsi ekonomi pada keluarga di Provinsi Jambi yang terbanyak adalah kategori baik $(35,43 \%)$ dan sangat baik $(18,56 \%)$, ini adalah salah satu Temuan dari Survei Kinerja dan Akuntabilitas Program KKBPK (SKAP) tahun 2018. Survey ini juga menemukan sebanyak 35,53 \% pelaksanaan fungsi ekonomi pada keluarga di Provinsi Jambi masuk kategori cukup. Temuan lainnya adalah kategori kurang dan sangat kurang masing-masing 9,50\% dan 1,17\% untuk pelaksanaan fungsi ekonomi pada keluarga di Provinsi Jambi.

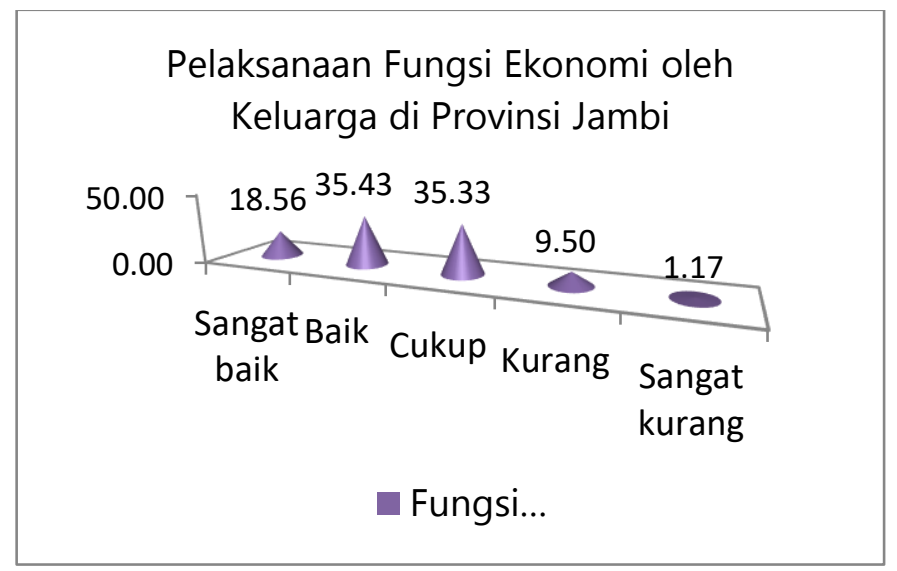

Gambar 8. Pelaksanaan Fungsi Ekonomi oleh Keluarga di Provinsi Jambi

\section{Pelaksanaan Fungsi Lingkungan}

Pelaksanaan fungsi lingkungan pada keluarga di Provinsi Jambi yang terbanyak termasuk masuk kategori cukup $(38,54 \%)$. Ini adalah salah satu temuan dari Survei Kinerja dan Akuntabilitas Program KKBPK (SKAP) tahun 2018. Temuan lain dari survey ini adalah pelaksanaan fungsi lingkungan pada keluarga di Provinsi Jambi yang juga agak banyak adalah kategori baik $(21,91 \%)$, kategori sangat baik (11,37 \%). Juga ditemukan dalam survey ini kategori kurang sebesar $25,81 \%$ dan sebagian kecil $(2,36 \%)$ bahwa pelaksanaan fungsi lingkungan pada keluarga di Provinsi Jambi termasuk masuk kategori sangat kurang.

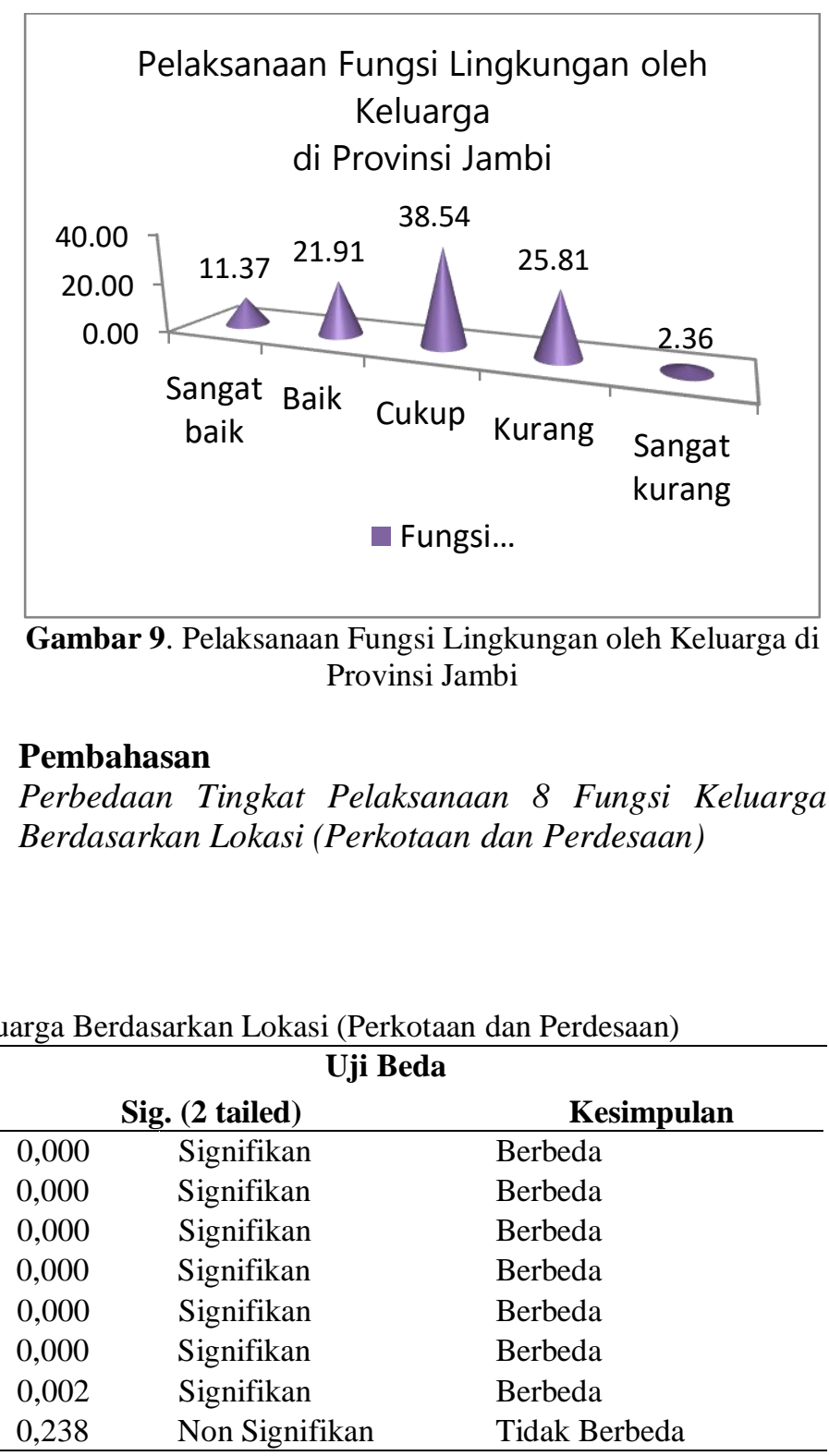

Tabel 4. Perbedaan Tingkat Pelaksanaan 8 Fungsi Keluarga Berdasarkan Lokasi (Perkotaan dan Perdesaan)

\begin{tabular}{clrcc}
\hline \multirow{2}{*}{ No } & \multicolumn{1}{c}{ Pelaksanaan 8 Fungsi Keluarga } & \multicolumn{2}{c}{ Uji Beda } & Kesimpulan \\
\cline { 1 - 4 } $\mathbf{1}$ & Fungsi Agama & 0,000 & Signifikan & Berbeda \\
$\mathbf{2}$ & Fungsi Sosial Budaya & 0,000 & Signifikan & Berbeda \\
$\mathbf{3}$ & Fungsi Cinta Kasih & 0,000 & Signifikan & Berbeda \\
$\mathbf{4}$ & Fungsi Perlindungan & 0,000 & Signifikan & Berbeda \\
$\mathbf{5}$ & Fungsi Reproduksi & 0,000 & Signifikan & Berbeda \\
$\mathbf{6}$ & Fungsi Sosialisasi dan Pendidikan & 0,000 & Signifikan & Berbeda \\
$\mathbf{7}$ & Fungsi Ekonomi & 0,002 & Signifikan & Berbeda \\
$\mathbf{8}$ & Fungsi Lingkungan & 0,238 & Non Signifikan & Tidak Berbeda \\
\hline
\end{tabular}

Sumber data: diolah

Berdasarkan Tabel di atas dapat ditarik kesimpulan tentang tingkat pelaksanaan 8 fungsi keluarga pada keluarga di perkotaan dan perdesaan Provinsi Jambi sebagai berikut :
1. Untuk fungsi agama diperoleh hasil signifikan 0,000 yang berarti berbeda. Hasil menyimpulkan bahwa pelaksanaan fungsi agama pada keluarga di perkotaan dan perdesaan Provinsi Jambi adalah berbeda atau 
tingkat pelaksanaan fungsi agama pada keluarga di perdesaan Provinsi Jambi lebih tinggi dibandingkan perkotaan Provinsi Jambi.

2. Hasil uji beda untuk fungsi sosial budaya diperoleh hasil signifikan 0,000 yang menunjukkan makna berbeda. Makna tersebut menjelaskan tingkat pelaksanaan fungsi sosial budaya pada keluarga di perdesaan Provinsi Jambi lebih tinggi dibandingkan perkotaan Provinsi Jambi.

3. Untuk fungsi cinta kasih diperoleh hasil signifikan 0,000. Berdasarkan hasil ini dapat dijelaskan bahwa pelaksanaan fungsi cinta kasih pada keluarga di perkotaan dan perdesaan Provinsi Jambi adalah berbeda atau tingkat pelaksanaan fungsi cinta kasih pada keluarga di perdesaan Provinsi Jambi lebih tinggi dibandingkan perkotaan Provinsi Jambi.

4. Uji beda pada fungsi perlindungan diperoleh hasil signifikan 0,000 yang berarti berbeda. Maka dapat diartikan bahwa pelaksanaan fungsi perlindungan pada keluarga di perkotaan dan perdesaan Provinsi Jambi adalah berbeda atau tingkat pelaksanaan fungsi perlindungan pada keluarga di perdesaan Provinsi Jambi lebih tinggi dibandingkan perkotaan Provinsi Jambi.

5. Untuk fungsi reproduksi diperoleh hasil signifikan 0,000 yang berarti signifikan. Maka pelaksanaan fungsi reproduksi pada keluarga di perkotaan dan perdesaan Provinsi Jambi adalah berbeda atau tingkat pelaksanaan fungsi reproduksi pada keluarga di perdesaan Provinsi Jambi lebih tinggi dibandingkan perkotaan Provinsi Jambi.

6. Berdasarkan hasil uji beda untuk fungsi sosialisasi dan pendidikan dengan nilai signifikan 0,000 dapat jelaskan bahwa pelaksanaan fungsi sosialisasi dan pendidikan pada keluarga di perkotaan dan perdesaan Provinsi Jambi adalah berbeda atau tingkat pelaksanaan fungsi sosialisasi dan pendidikan pada keluarga di perdesaan Provinsi Jambi lebih tinggi dibandingkan perkotaan Provinsi Jambi.

7. Pada fungsi ekonomi yang dilakukan uji beda diperoleh nilai signifikan sebesar 0,002 yang berarti signifikan. Makna dari signfikasi tersebut adalah pelaksanaan fungsi ekonomi pada keluarga di perkotaan dan perdesaan Provinsi Jambi adalah berbeda atau tingkat pelaksanaan fungsi ekonomi pada keluarga di perdesaan Provinsi Jambi lebih tinggi dibandingkan perkotaan Provinsi Jambi.

8. Hasil uji beda untuk fungsi lingkungan mempunyai nilai signifikan 0,238 yang mempunyai arti tidak signifikan. Maka dapat dijelaskan bahwa pelaksanaan fungsi lingkungan pada keluarga di perkotaan dan perdesaan Provinsi Jambi adalah tidak berbeda atau sama.

\section{Ketahanan Keluarga}

Tabel 5. Pengetahuan Keluarga Tentang Ketahanan Keluarga

\begin{tabular}{|c|c|c|c|}
\hline \multirow{2}{*}{ No } & \multirow{2}{*}{ Ketahanan Keluarga } & \multicolumn{2}{|c|}{ Pengetahuan (\%) } \\
\hline & & Ya & Tidak \\
\hline 1 & Bina Keluarga Balita (BKB) & 37.90 & 62.10 \\
\hline 2 & Bina Keluarga Remaja (BKR) & 21.00 & 79.00 \\
\hline 3 & Bina Keluarga Lansia (BKL) & 36.30 & 63.70 \\
\hline 4 & Pusat Informasi dan Konseling Remaja (PIK-R) & 9.40 & 90.60 \\
\hline 5 & Pusat Pelayanan Keluarga Sejahtera (PPKS) & 18.70 & 81.30 \\
\hline 6 & Usaha Peningkatan Pendapatan Keluarga Sejahtera (UPPKS) & 31.10 & 68.90 \\
\hline
\end{tabular}

Sumber data: diolah

\section{Tingkat Pengetahuan Tentang \\ Ketahanan Keluarga \\ di Provinsi Jambi}

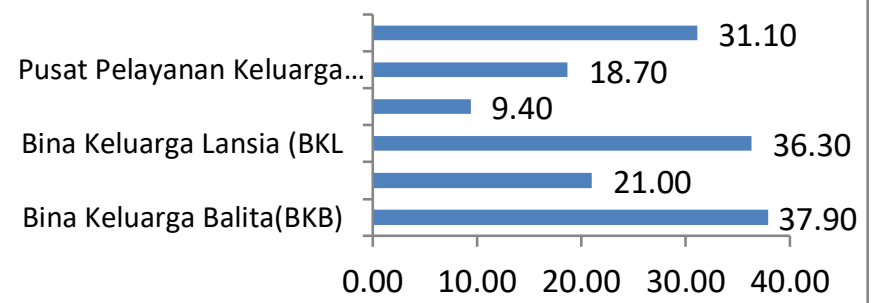

Tingkat Pengetahuan Tentang Ketahanan Keluarga

Gambar 10. Tingkat Pengetahuan Tentang Ketahanan Keluarga di Provinsi Jambi
Berdasarkan Tabel di atas dapat dijelaskan tingkat pengetahuan keluarga di Provinsi Jambi tentang Ketahanan Keluarga adalah sebagai berikut :

1. Mayoritas masyarakat di Provinsi Jambi tidak mengetahui $(62,10 \%)$ mengenai Kelompok Kegiatan Bina Keluarga Balita (BKB), hanya sebagai kecil $(37,90 \%)$ yang mengenai Kelompok Kegiatan Bina Keluarga Balita (BKB). Upaya yang dilakukan untuk membina keluarga yang memiliki balita dan anak adalah dengan membentuk Kelompok Kegiatan (Poktan) Bina Keluarga Balita (BKB). Poktan ini bertujuan untuk memberikan informasi kepada keluarga yang mempunyai balita dan anak tentang tumbuh kembang dan pengasuhannya.

2. Sebagian besar keluarga di Provinsi Jambi tidak mengetahui $(79,00 \%)$ mengenai Kelompok Kegiatan Bina Keluarga Remaja (BKR), hanya sebagai kecil 
$(21,00 \%)$ yang mengenai Kelompok Kegiatan Bina Keluarga Remaja (BKR). Pembinaan terhadap remaja dilakukan melalui Program Generasi Berencana (GenRe), program ini dilakukan melalui salah satu pendekatan yaitu kepada keluarga yang memiliki anak berusia remaja melalui poktan Bina Keluarga Remaja (BKR). Program GenRe dibentuk dengan tujuan meningkatkan kesadaran remaja dalam kesehatan reproduksi

3. Keluarga di Provinsi Jambi dominan tidak mengetahui $(63,70 \%)$ mengenai Kelompok Kegiatan Bina Keluarga Lansia (BKL), hanya sebagai kecil $(36,30 \%)$ yang mengenai Kelompok Kegiatan Bina Keluarga Lansia (BKL). Sementara itu, pembinaan terhadap keluarga yang memiliki lansia dan lansianya sendiri dilakukan melalui pembentukan Poktan Bina Keluarga Lansia (BKL). Poktan ini dibentuk dengan tujuan untuk memberdayakan lansia (BKKBN, 2016).

4. Di Provinsi Jambi, mayoritas keluarga tidak mengetahui $(90,60 \%)$ mengenai Usaha Peningkatan Pendapatan Keluarga Sejahtera (UPPKS), hanya sebagai kecil $(9,40 \%)$ yang mengenai Kelompok Kegiatan Pusat Informasi dan Konseling Remaja (PIK-R). Pembinaan terhadap remaja dilakukan melalui Program Generasi Berencana (GenRe), program ini dilakukan salah satunya melalui pendekatan yaitu kepada remaja langsung melalui Pusat Informasi dan Konseling Remaja/Mahasiswa (PIK-R/M)

5. Di Provinsi Jambi, hasil Survei Kinerja dan Akuntabilitas Program Kependudukan, Keluarga Berencana dan Pembangunan Keluarga (SKAP) tahun 2018 melaporkan sebagian besar keluarga tidak mengetahui $(81,30 \%)$ mengenai Kelompok Kegiatan Pusat Pelayanan Keluarga Sejahtera (PPKS), hanya sebagai kecil $(18,70 \%)$ yang mengenai Kelompok Kegiatan Pusat Pelayanan Keluarga Sejahtera (PPKS).

6. Survei Kinerja dan Akuntabilitas Program Kependudukan, Keluarga Berencana dan Pembangunan Keluarga (SKAP) tahun 2018 juga melaporkan Keluarga di Provinsi Jambi dominan tidak mengetahui $(68,90 \%)$ mengenai Kelompok Kegiatan Bina Keluarga Lansia (BKL), hanya sebagai kecil $(31,10 \%)$ yang mengenai Usaha Peningkatan Pendapatan Keluarga Sejahtera (UPPKS). UPPKS ini merupakan suatu pembelajaran usaha ekonomi produktif bagi kelompok akseptor KB, khususnya Pra-Keluarga Sejahtera (Pra-KS) dan Keluarga Sejahtera I (KS I).
Keaktifan Keluarga Terhadap Ketahanan Keluarga

Tabel 6. Keaktifan Keluarga Terhadap Ketahanan Keluarga

\begin{tabular}{|c|c|c|c|}
\hline \multirow{2}{*}{ No } & \multirow{2}{*}{ Ketahanan Keluarga } & \multicolumn{2}{|c|}{ Keaktifan $(\%)$} \\
\hline & & Ya & Tidak \\
\hline 1 & Bina Keluarga Balita (BKB) & 0.60 & 99.40 \\
\hline 2 & Bina Keluarga Remaja (BKR) & 0.20 & 99.80 \\
\hline 3 & Bina Keluarga Lansia (BKL) & 3.00 & 97.00 \\
\hline
\end{tabular}

Sumber data: diolah

Tingkat Keaktifan terhadap Ketahanan Keluarga

di Provinsi Jambi

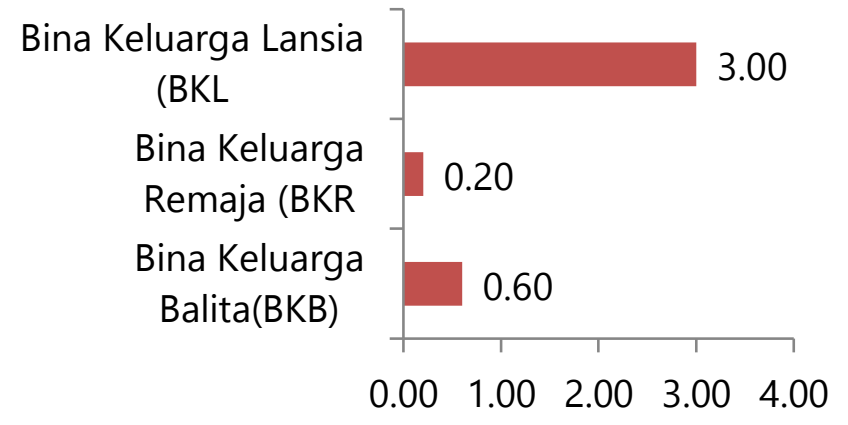

Tingkat Pengetahuan terhapap Ketahanan Keluarga

Gambar 11. Tingkat Keaktifan terhadapa Ketahanan Keluarga di Provinsi Jambi

Berdasarkan Tabel di atas terlihat tingkat keaktifan keluarga di Provinsi Jambi tentang Ketahanan Keluarga berupa kelompok kegiatan (Poktan) Tribina (BKB, BKR, BKL) sangat rendah. Tingkat keaktifan yang tertinggi terjadi pada kelompok kegiatan Bina Keluarga Lansia (BKL) (3,00 \%), sedangkan untuk kelompok kegiatan Tribina yang lain (BKB, BKR) kurang dari $1,00 \%$.

Perbedaan Pengetahuan dan Keaktifan Keluarga Terhadap Ketahanan Keluarga Berdasarkan Lokasi (Perkotaan dan Perdesaan)

Berdasarkan Tabel di bawah ini dapat ditarik kesimpulan tentang tingkat pengetahuan keluarga terhadap ketahanan keluarga pada keluarga di perkotaan dan perdesaan Provinsi Jambi sebagai berikut : 
Tabel 7. Perbedaan Pengetahuan dan Keaktifan Keluarga Terhadap Ketahanan Keluarga Berdasarkan Lokasi (Perkotaan dan Perdesaan)

\begin{tabular}{|c|c|c|c|c|}
\hline \multirow{2}{*}{ No } & \multirow{2}{*}{ Pengetahuan tentang Ketahanan Keluarga } & \multicolumn{3}{|c|}{ Uji Beda } \\
\hline & & \multicolumn{2}{|c|}{ Sig. (2 tailed) } & Kesimpulan \\
\hline 1 & Bina Keluarga Balita (BKB) & 0,011 & Signifikan & Berbeda \\
\hline 2 & Bina Keluarga Remaja (BKR) & 0,194 & Non Signifikan & Tidak Berbeda \\
\hline 3 & Bina Keluarga Lansia (BKL) & 0,000 & Signifikan & Berbeda \\
\hline 4 & Pusat Informasi dan Konseling Remaja (PIK-R) & 0,000 & Signifikan & Berbeda \\
\hline 5 & Pusat Pelayanan Keluarga Sejahtera (PPKS) & 0,075 & Non Signifikan & Tidak Berbeda \\
\hline 6 & Usaha Peningkatan Pendapatan Keluarga Sejahtera (UPPKS) & 0,000 & Signifikan & Berbeda \\
\hline
\end{tabular}

Sumber data: diolah

1. Untuk Bina Keluarga Balita (BKB) diperoleh hasil signifikan 0,011 yang lebih kecil dari $\alpha 5 \%$ yang berarti signifikan. Makna signifikan tersebut adalah tingkat pengetahuan keluarga tentang kelompok kegiatan Bina Keluarga Balita (BKB) di perkotaan dan perdesaan Provinsi Jambi adalah berbeda atau tingkat pengetahuan keluarga tentang kelompok kegiatan Bina Keluarga Balita (BKB) di perdesaan Provinsi Jambi lebih tinggi dibandingkan perkotaan Provinsi Jambi.

2. Uji beda untuk Bina Keluarga Remaja (BKR) diperoleh hasil signifikan 0,194 yang lebih besar dari a $5 \%$ yang berarti tidak signifikan. Tidak signifikan tersebut menunjukkan bahwa tingkat pengetahuan keluarga tentang kelompok kegiatan Bina Keluarga Remaja (BKR) di perkotaan dan perdesaan Provinsi Jambi adalah tidak berbeda atau sama.

3. Berdasarkan uji beda diperoleh nilai signifikan 0,000 untuk Untuk Bina Keluarga Lansia (BKL) diperoleh hasil. Nilai signifikasi tersebut lebih kecil dari $\alpha 5 \%$ yang berarti signifikan. Maka dapat disimpulkan bahwa tingkat pengetahuan keluarga tentang kelompok kegiatan Bina Keluarga Lansia (BKL) di perkotaan dan perdesaan Provinsi Jambi adalah berbeda atau tingkat pengetahuan keluarga tentang kelompok kegiatan Bina Keluarga Lansia (BKL) di perdesaan Provinsi Jambi lebih tinggi dibandingkan perkotaan Provinsi Jambi.

4. Untuk Pusat Informasi dan Konseling Remaja (PIKR) diperoleh hasil signifikan 0,000 yang lebih kecil dari $\alpha 5 \%$ yang berarti signifikan. Makna signifikan tersebut adalah tingkat pengetahuan keluarga tentang Pusat Informasi dan Konseling Remaja (PIK-R) di perkotaan dan perdesaan Provinsi Jambi adalah berbeda atau tingkat pengetahuan keluarga tentang Pusat Informasi dan Konseling Remaja (PIK-R) di perdesaan Provinsi Jambi lebih tinggi dibandingkan perkotaan Provinsi Jambi.

5. Berdasarkan uji beda diperoleh hasil signifikan 0,075 yang lebih besar dari a $5 \%$ yang berarti tidak signifikan untuk Pusat Pelayanan Keluarga Sejahtera (PPKS). Kesimpulan yang dapat diambil dari fakta tersebut adalah tingkat pengetahuan keluarga tentang Pusat Pelayanan Keluarga Sejahtera (PPKS) di perkotaan dan perdesaan Provinsi Jambi adalah tidak berbeda atau sama.

6. Hasil uji beda untuk Usaha Peningkatan Pendapatan Keluarga Sejahtera (UPPKS) adalah signifikan dengan nilai signifikan 0,000 yang lebih kecil dari $\alpha$ $5 \%$. Berarti tingkat pengetahuan keluarga tentang Usaha Peningkatan Pendapatan Keluarga Sejahtera (UPPKS) di perkotaan dan perdesaan Provinsi Jambi adalah berbeda atau tingkat pengetahuan keluarga tentang Usaha Peningkatan Pendapatan Keluarga Sejahtera (UPPKS) di perdesaan Provinsi Jambi lebih tinggi dibandingkan perkotaan Provinsi Jambi.

Berikut ini adalah perbedaan tingkat keaktifan keluarga di Provinsi Jambi antara keluarga di perkotaan dengan perdesaan terhadap ketahanan keluarga berupa kelompok kegiatan (Poktan) Tribina (BKB, BKR, BKL), secara rinci tersaji pada Tabel berikut ini :

Tabel 8. perbedaan tingkat keaktifan keluarga di Provinsi Jambi antara keluarga di perkotaan dengan perdesaan terhadap ketahanan keluarga berupa kelompok kegiatan (Poktan) Tribina (BKB, BKR, BKL)

\begin{tabular}{|c|c|c|c|c|}
\hline \multirow{2}{*}{ No } & \multirow{2}{*}{ Keaktifan terhadap Ketahanan Keluarga } & \multicolumn{3}{|c|}{ Uji Beda } \\
\hline & & \multicolumn{2}{|c|}{ Sig. (2 tailed) } & Kesimpulan \\
\hline 1 & Bina Keluarga Balita (BKB) & 0,221 & Non Signifikan & Tidak Berbeda \\
\hline 2 & Bina Keluarga Remaja (BKR) & 0,060 & Non Signifikan & Tidak Berbeda \\
\hline 3 & Bina Keluarga Lansia (BKL) & 0,000 & Signifikan & Berbeda \\
\hline 4 & Usaha Peningkatan Pendapatan Keluarga Sejahtera (UPPKS) & 0,469 & Non Signifikan & Tidak Berbeda \\
\hline
\end{tabular}

Sumber data: diolah

1. Untuk Bina Keluarga Balita (BKB) diperoleh hasil signifikan 0,221 yang lebih besar dari $\alpha 5 \%$ yang berarti tidak signifikan. Berdasarkan hasil dapat dijelaskan bahwa tingkat keaktiftan keluarga tentang kelompok kegiatan Bina Keluarga Balita (BKB) di 
perkotaan dan perdesaan Provinsi Jambi adalah tidak berbeda atau sama.

2. Begitu pula dengan Bina Keluarga Remaja (BKR), hasil uji beda diperoleh hasil signifikan 0,060 yang lebih besar dari $\alpha 5 \%$ yang berarti tidak signifikan. Berdasarkan hasil dapat dijelaskan bahwa tingkat keaktiftan keluarga tentang kelompok kegiatan Bina Keluarga Balita (BKB) di perkotaan dan perdesaan Provinsi Jambi adalah tidak berbeda atau sama.

3. Hasil uji beda untuk Usaha Peningkatan Pendapatan Keluarga Sejahtera (UPPKS) adalah signifikan dengan nilai signifikan 0,000 yang lebih kecil dari $\alpha$ $5 \%$. Berarti tingkat keaktiftan keluarga tentang Usaha Peningkatan Pendapatan Keluarga Sejahtera (UPPKS) di perkotaan dan perdesaan Provinsi Jambi adalah berbeda atau tingkat keaktiftan keluarga tentang Usaha Peningkatan Pendapatan Keluarga Sejahtera (UPPKS) di perdesaan Provinsi Jambi lebih tinggi dibandingkan perkotaan Provinsi Jambi.

4. Selanjutnya, untuk Bina Keluarga Lansia (BKL), hasil uji beda diperoleh hasil signifikan 0,469 yang lebih besar dari $\alpha 5 \%$ yang berarti tidak signifikan. Berdasarkan hasil dapat dijelaskan bahwa tingkat keaktiftan keluarga tentang kelompok kegiatan Bina Keluarga Lansia (BKL) di perkotaan dan perdesaan Provinsi Jambi adalah tidak berbeda atau sama.

\section{Pengaruh Faktor Pendidikan Terhadap Keaktifan Ketahanan Keluarga dan Pelaksanaan 8 Fungsi Keluarga}

Untuk mengetahui pengaruh pendidikan kelaurga terhadap Pelaksanaan 8 Fungsi Keluarga dan Keaktifan Ketahanan Keluarga digunakan analisis Regresi Sederhana. Hasil analisis regresi tersaji pada Tabel berikut ini.

Tabel 9. Pengaruh Faktor Pendidikan Terhadap Keaktifan Ketahanan Keluarga dan Pelaksanaan 8 Fungsi Keluarga

\begin{tabular}{ccccc}
\hline \multirow{2}{*}{ No } & \multirow{2}{*}{$\mathbf{8}$ Fungsi Keluarga } & \multicolumn{2}{c}{ Regresi } \\
\cline { 1 - 1 } $\mathbf{1}$ & & 8 Fungsi Keluarga & 8,239 & 0,000 \\
$\mathbf{2}$ & Fungsi Agama & 5,335 & 0,000 \\
$\mathbf{3}$ & Fungsi Sosial Budaya & 6,798 & 0,000 \\
$\mathbf{4}$ & Fungsi Cinta Kasih & 7,639 & 0,000 \\
$\mathbf{5}$ & Fungsi Perlindungan & 4,959 & 0,000 \\
$\mathbf{6}$ & Fungsi Reproduksi & 9,791 & 0,000 \\
$\mathbf{7}$ & Fungsi Sosialisasi dan & 8,171 & 0,000 \\
$\mathbf{8}$ & Pendidikan & Fungsi Ekonomi & 5,547 & 0,000 \\
$\mathbf{9}$ & Fungsi Lingkungan & 5,818 & 0,000 \\
$\mathbf{1 0}$ & Ketahanan Keluarga & $\mathbf{0 , 2 4 3}$ & $\mathbf{0 , 0 8 0}$ \\
\hline
\end{tabular}

Sumber data: diolah

1. Hasil analisis regresi untuk 8 fungsi keluarga, uji partial diperoleh nilai $t_{\text {hitung }}=8,239$ dengan sig. 0,000 . Hasil ini menunjukkan bahwa pendidikan berpengaruh terhadap pelaksanaan 8 fungsi keluarga di Provinsi Jambi. Pengaruhnya positif yang berarti semakin tinggi pendidikan kepala keluarga maka semakin tinggi pelaksanaan 8 fungsi keluarga di Provinsi Jambi.

a. Semakin tinggi pendidikan kepala keluarga maka semakin tinggi pelaksanaan fungsi agama pada keluarga di Provinsi Jambi

b. Semakin tinggi pendidikan kepala keluarga maka semakin tinggi pelaksanaan fungsi sosial budaya pada keluarga di Provinsi Jambi

c. Semakin tinggi pendidikan kepala keluarga maka semakin tinggi pelaksanaan fungsi cinta kasih pada keluarga di Provinsi Jambi

d. Semakin tinggi pendidikan kepala keluarga maka semakin tinggi pelaksanaan fungsi perlindungan pada keluarga di Provinsi Jambi

e. Semakin tinggi pendidikan kepala keluarga maka semakin tinggi pelaksanaan fungsi sosial dan pendidikan pada keluarga di Provinsi Jambi

f. Semakin tinggi pendidikan kepala keluarga maka semakin tinggi pelaksanaan fungsi ekonomi pada keluarga di Provinsi Jambi

g. Semakin tinggi pendidikan kepala keluarga maka semakin tinggi pelaksanaan fungsi lingkungan pada keluarga di Provinsi Jambi

2. Hasil analisis regresi untuk ketahanan keluarga, uji partial diperoleh nilai $t_{\text {hitung }}=0,243$ dengan sig. 0,080 . Hasil ini menunjukkan bahwa pendidikan tidak berpengaruh terhadap keaktifan ketahanan keluarga di Provinsi Jambi. Hasil ini memberikan informasi bahwa rendah tinggi tingkat pendidikan kepala keluarga tidak menyebabkan rendah tinggi keaktifan ketahanan keluarga di Provinsi Jambi.

\section{SIMPULAN}

1. Untuk pelaksanaan 8 fungsi keluarga di Provinsi Jambi dapat disimpulkan sebagai berikut :

a. Mayoritas keluarga di Provinsi Jambi $(86,60 \%)$ tidak mengetahui tentang 8 fungsi keluarga, hanya sebagian kecil saja $(13,40 \%)$ yang mengetahui tentang 8 fungsi keluarga.

b. Pelaksanaan 8 fungsi keluarga di Provinsi Jambi yang terbanyak (43,82\%) kategori cukup, diikuti kategori baik $(29,27 \%)$ dan sangat baik $(19,52 \%)$, kurang $(3,70 \%)$ dan sangat kurang $(3,69 \%)$.

c. Pelaksanaan 8 fungsi keluarga di Provinsi Jambi yang terdiri dari fungsi agama, fungsi sosial budaya, fungsi cinta kasih, fungsi perlindungan, fungsi reproduksi, fungsi sosialisasi dan pendidikan, ekonomi, dan fungsi lingkungan pada keluarga di perkotaan dan perdesaan Provinsi Jambi adalah berbeda kecuali fungsi lingkungan

2. Untuk keaktifan ketahanan keluarga di Provinsi Jambi dapat disimpulkan sebagai berikut : 
a. Mayoritas keluarga di Provinsi Jambi tidak mengetahui mengenai Kelompok Kegiatan (Poktan) Tribina (BKB, BKR, BKL), PIK R/M, UPPKS dan PPKS

b. Tingkat keaktifan keluarga di Provinsi Jambi tentang Ketahanan Keluarga berupa kelompok kegiatan (Poktan) Tribina (BKB, BKR, BKL) sangat rendah. Tingkat keaktifan yang tertinggi terjadi pada kelompok kegiatan Bina Keluarga Lansia (BKL) (3,00 \%), sedangkan untuk kelompok kegiatan Tribina yang lain (BKB, BKR) kurang dari $1,00 \%$.

c. Tingkat keaktifan Ketahanan keluarga di Provinsi Jambi beragam antara perkotaan dan perdesaan

3. Semakin tinggi pendidikan kepala keluarga maka semakin tinggi pelaksanaan 8 fungsi keluarga di Provinsi Jambi, tetapi rendah tinggi tingkat pendidikan kepala keluarga tidak menyebabkan rendah tinggi keaktifan ketahanan keluarga di Provinsi Jambi

\section{DAFTAR PUSTAKA}

Badan Kependudukan dan Keluarga Berencana Nasional. 2012. Buku Pegangan Kader Tentang Bimbingan dan Pembinaan Keluarga Remaja. Jakarta

Badan Kependudukan dan Keluarga Berencana Nasional. 2013. Buku Pegangan Kader BKR Tentang Delapan fungsi keluarga. Jakarta

Chapman, G. 2000. Five Signs of a Functional Family (Lima Tanda Keluarga yang Mantap). Batam: Interaksara

Creswell, J. W. 2014. Research Design: Qualitative, Quantitative and Mixed Methods Approaches, 4 Edition. London: Sage

Erlina, 2008, Metodologi Penelitian bisnis: untuk akuntansi dan manajemen, Edisi Kedua, Cetakan Pertama, USU Press, Medan.

Friedman, 1998. Keperawatan Keluarga. Jakarta : EGC

Hendri, Jhon. (2009). Riset Pemasaran. Merancang Kuesioner. Universitas Gunadarma.

McCubbin, H.I., Joy. C.B., Cauble, A.E., Comeau, J.K., Patterson, J.M., \& Needle, R.H. 1980. Family stress and coping: A decade review. Journal of Marriage and the Family, 42, 855-871.

Moehar, D. 2002. Metode Penelitian Sosial Ekonomi. Jakarta : Bumi Aksara.

Pearsall, P. 1996. Rahasia Kekuatan Keluarga : Membangkitkan Kekuatan Hidup Keluarga untuk Memperkokoh Membangkitkan Kembali, dan Menyembuhkan. Pustaka Delapratasa. Jakarta.

Riduan dan Kuncoro E.A, 2007. Cara Menggunakan dan Memaknai Analisis Jalur (Path Analysis). Alfabeta. Bandung.

Sunarti, E. 2001. Studi Ketahanan Keluarga dan Ukurannya: Telaah Kasus Pengaruhnya Terhadap
Kualitas Kehamilan. Disertasi yang Tidak Dipublikasikan. Program Pascasarjana. Institut Pertanian Bogor

Survei Kinerja dan Akuntabilitas Program (SKAP) Badan Kependudukan dan Keluarga Berencana Nasional Tahun 2018

Rahmawati, I., Purnomi, I., dan Latif, V, N. 2016. Strategi Penguatan 8 Fungsi Keluarga Dalam Pencegahan TRIAD KRR (Seksualitas, Napza, HIV \& AIDS) Di Kota Pekalongan. Jurnal Pena Medika. Vol. 6, No. 1, Juni 2016 : 46 - 57

Rencana Pembangunan Jangka Menengah Nasional Tahun 2015-2019

Renstra Badan Kependudukan dan Keluarga Berencana Nasional (BKKBN) Tahun 2015-2019

Undang-Undang Nomor 10 Tahun 1992 Perkembangan Kependudukan dan Pembangunan Keluarga Sejahtera

Undang-Undang Nomor 52 Tahun 2009 tentang Perkembangan Kependudukan dan Pembangunan Keluarga

Undang-Undang Nomor 17 Tahun 2007 tentang Rencana Pembangunan Jangka Panjang Nasional Tahun 2005-2025 